\title{
Oxidative stress induced by the chemotherapeutic agent arsenic trioxide
}

\author{
Mathews V. Varghese - Alex Manju • \\ M. Abhilash • M. V. Sauganth Paul • \\ S. Abhilash $\cdot$ R. Harikumaran Nair
}

Received: 17 July 2013/ Accepted: 27 August 2013/Published online: 13 September 2013

(C) The Author(s) 2013. This article is published with open access at Springerlink.com

\begin{abstract}
Arsenic compounds have been used for medicinal purposes throughout history. Arsenic trioxide $\left(\mathrm{As}_{2} \mathrm{O}_{3}\right)$ achieved dramatic remissions in patients with acute promyelocytic leukaemia. Unfortunately, the clinical usefulness of $\mathrm{As}_{2} \mathrm{O}_{3}$ has been limited by its toxicity. The present study was designed to investigate the toxic effects of $\mathrm{As}_{2} \mathrm{O}_{3}$ at its clinical concentrations. Experimental rats were administered with $\mathrm{As}_{2} \mathrm{O}_{3} 2,4$ and $8 \mathrm{mg} / \mathrm{kg}$ body weight for a period of 45 days and the serum glucose, creatine kinase, lactate dehydrogenase, lipid peroxidation and antioxidant status were measured. $\mathrm{As}_{2} \mathrm{O}_{3}$-treated rats showed elevated serum glucose, creatine kinase and lactate dehydrogenase concentrations. Lipid peroxidation product malondialdehyde was found to be produced more in arsenic-treated rats. Reduced glutathione and glutathionedependant antioxidant enzymes, glutathione- $S$-transferase and glutathione peroxidase, and the antiperoxidative enzymes, superoxide dismutase and catalase, concentrations were reduced with the $\mathrm{As}_{2} \mathrm{O}_{3}$ treatment. All these toxic effects were found increased with the increase in concentration of $\mathrm{As}_{2} \mathrm{O}_{3}$. The results of the study indicate that $\mathrm{As}_{2} \mathrm{O}_{3}$ produced dose-dependant toxic side effects at its clinical concentrations.
\end{abstract}

Keywords Arsenic trioxide - Antioxidants . Lipid peroxidation $\cdot$ Glutathione $\cdot$ Oxidative stress

M. V. Varghese - A. Manju - M. Abhilash ·

M. V. S. Paul - S. Abhilash · R. H. Nair $(\varangle)$

School of Biosciences, Mahatma Gandhi University,

P.D Hills P.O, Kottayam 686560, Kerala, India

e-mail: harinair@mgu.ac.in

\section{Introduction}

Arsenic is widely distributed in air, water and soil in the form of either metalloids or chemical compound (Basu et al. 2001). The most toxicologically potent arsenic compounds are in the trivalent oxidation state (Hughes 2002). Exposure to arsenic occurs via ingestion, inhalation, dermal contact, and the parenteral route (Tchounwou et al. 1999). The health effects that are associated with arsenic exposure include cardiovascular and peripheral vascular disease, developmental anomalies, neurologic and neurobehavioral disorders, diabetes, portal fibrosis, and multiple cancers (Tseng et al. 2003). Haematological abnormalities associated with arsenic intoxication are haemoglobinuria, intravascular coagulation, bone marrow depression, severe pancytopenia, and normocytic normochromic anaemia and basophilic stippling (Ratnaike 2003).

The treatment with low doses of arsenic trioxide $\left(\mathrm{As}_{2} \mathrm{O}_{3}\right)$ caused high rates of complete remission in patients suffering from acute promyelocytic leukaemia (APL) (Wang and Chen 2008). The adverse effects associated with $\mathrm{As}_{2} \mathrm{O}_{3}$ treatment include hyperleukocytosis, APL differentiation syndrome, electrocardiographic abnormalities (QTc-interval prolongation), peripheral neuropathy, skin rash, gastrointestinal reactions and hyperglycaemia (Rust and Soignet 2001). Arsenic compounds also showed genotoxic effects; induced gene amplification, inhibit DNA repair, and induce expression of the oxidative stress protein heme oxygenase in mammalian cells (Vega et al. 1995; Keyse et al. 1990).

Due to the toxic side effects of arsenic, it carries significant risks in their therapeutic regiment. The mechanisms of arsenic-induced toxic effects during clinical trials were not fully elucidated. So the present study was 
performed to understand the toxicological association between biochemical parameters and the blood antioxidant status at different clinically relevant concentrations of $\mathrm{As}_{2} \mathrm{O}_{3}$.

\section{Materials and methods}

\section{Chemicals}

Arsenic trioxide, sodium pyruvate, thiobarbituric acid and triton X-100, phenazine methosulphate, nitroblue tetrazolium were obtained from Sigma-Aldrich (Bangalore, India). L-aspartate, $\alpha$-oxoglutarate, 2,4-dinitro phenyl hydrazine, nicotinamide adenine dinucleotide (reduced), 1-chloro-2,4-dinitrobenzene (CDNB), 5,5'-dithiobis-(2nitrobenzoic acid), nicotinamide adenine dinucleotide phosphate and reduced glutathione were purchased from Merck Specialties Pvt Ltd (Mumbai, India). All other chemicals were purchased from Sisco Research Laboratories (Mumbai, Maharashtra, India).

\section{Experimental animals}

Male albino rats of Wistar strain (200-220 g) were purchased from Small Animal Breeding Station of Government Veterinary College, Mannuthy, Thrissur, Kerala, India. The animals were housed in polypropylene cages kept in the animal house of School of Biosciences, Mahatma Gandhi University, Kottayam. All the animals were maintained under standard laboratory conditions of temperature $\left(22 \pm 3{ }^{\circ} \mathrm{C}\right)$ and 12-h light and dark cycles throughout the experimental period. Rats were provided with laboratory chow (Hindustan Unilever Ltd., Mumbai, India) and water ad libitum. Experiments were conducted as per the guidelines of Institutional Animal Ethical Committee, School of Biosciences, Mahatma Gandhi University (Reg. No. B1662009/2). After 2 weeks of acclimation, animals were randomly divided into four groups with six animals in each group.

(a) Group 1: Normal Control

(b) Group 2: $\mathrm{As}_{2} \mathrm{O}_{3} 2 \mathrm{mg} / \mathrm{kg}$ b.wt

(c) Group 3: $\mathrm{As}_{2} \mathrm{O}_{3} 4 \mathrm{mg} / \mathrm{kg}$ b.wt

(d) Group 4: $\mathrm{As}_{2} \mathrm{O}_{3} 8 \mathrm{mg} / \mathrm{kg}$ b.wt

The duration of the study was 45 days and the route of administration was daily by oral intubation. At the end of the experimental period, blood was drawn from the orbital sinus of the rat's eye. Anticoagulated blood was used for the analysis of blood antioxidant status and lipid peroxidation. The blood samples collected in another set of test tubes without anticoagulant were centrifuged at 3,000 rpm at $4{ }^{\circ} \mathrm{C}$ for $20 \mathrm{~min}$; the clear serum obtained was used for the biochemical assays.
Analysis of serum glucose, creatine kinase and lactate dehydrogenase

Serum Glucose, Creatine Kinase (CK) and Lactate dehydrogenase (LDH) were detected (Agappe Diagnostic Ltd., Ernakulam, Kerala, India) using semi-auto analyzer (RMS, India).

Analysis of blood antioxidant status and lipid peroxidation

Haemoglobin concentration in blood was determined according to the method of Drabkin and Austin (1932). Superoxide dismutase (SOD) activity was determined by the method of Paoletti et al. (1986). Catalase (CAT) activity was measured in the sample according to the method of Aebi (1984) by measuring the decrease in absorbance of hydrogen peroxide $\left(\mathrm{H}_{2} \mathrm{O}_{2}\right)$ at $240 \mathrm{~nm}$. Glutathione-S-Transferase (GST) activity was estimated by determining the rate of formation of glutathione and CDNB conjugates (Beutler et al. 1986). Glutathione peroxidase (GPx) activity was measured by the method of Paglia and Valentine (1967). Reduced glutathione (GSH) was estimated by the method of Beutler et al. (1963). Malondialdehyde (MDA), a product of lipid peroxidation, was determined by the method of Buege and Aust (1978).

Statistical analysis

One-way ANOVA followed by LSD post hoc multiple comparison test was used for comparison among the four groups (SPSS/PC+ version 18, SPSS Inc. Chicago, Illinois, USA). Probability $(p)<0.05$ was considered statistically significant.

\section{Results}

$\mathrm{As}_{2} \mathrm{O}_{3}$-induced alterations in the serum Glucose, $\mathrm{CK}$ and $\mathrm{LDH}$

$\mathrm{As}_{2} \mathrm{O}_{3}$ treatment significantly $(p<0.05)$ increased the serum Glucose (Fig. 1), CK (Fig. 2) and LDH (Fig. 3) when compared to the group I control. These biochemical parameters also showed statistical significance $(p<0.05)$ when compared between groups II, III and IV. The concentrations of Glucose, CK and LDH were increased with respect to the increase in concentration of $\mathrm{As}_{2} \mathrm{O}_{3}$.

$\mathrm{As}_{2} \mathrm{O}_{3}$-induced lipid peroxidation

The lipid peroxidation product MDA was significantly increased with $\mathrm{As}_{2} \mathrm{O}_{3}$ treatment when compared to the 


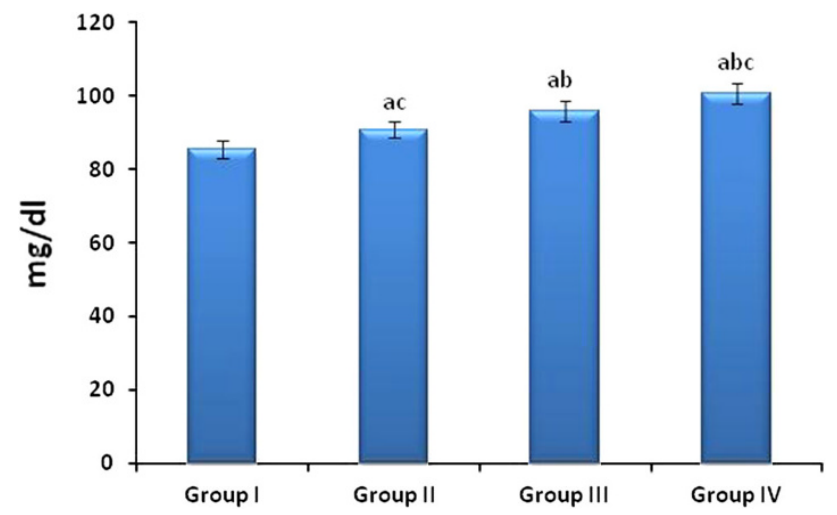

Fig. 1 Effect of $\mathrm{As}_{2} \mathrm{O}_{3}$ on Serum Glucose: Normal control (Group I), $\mathrm{As}_{2} \mathrm{O}_{3} 2 \mathrm{mg} / \mathrm{kg}$ b.wt (Group II), $\mathrm{As}_{2} \mathrm{O}_{3} 4 \mathrm{mg} / \mathrm{kg}$ b.wt (Group III), and $\mathrm{As}_{2} \mathrm{O}_{3} 8 \mathrm{mg} / \mathrm{kg}$ b.wt (Group IV). Data represented as mean $\pm \mathrm{SD}$,

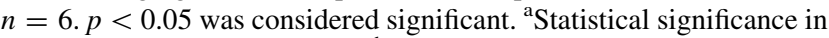
comparison to normal control, ${ }^{b}$ statistical significance in comparison to group II, and ${ }^{\mathrm{c}}$ statistical significance in comparison to group III

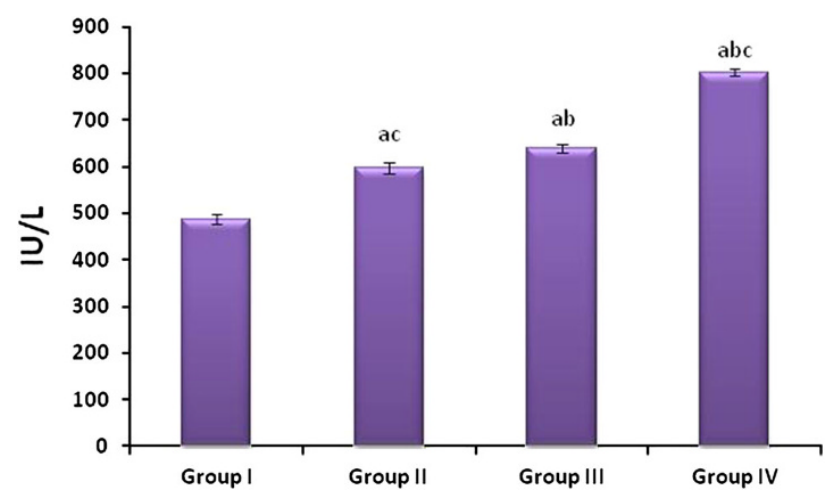

Fig. 2 Effect of $\mathrm{As}_{2} \mathrm{O}_{3}$ on Creatine Kinase: Normal control (Group I), $\mathrm{As}_{2} \mathrm{O}_{3} 2 \mathrm{mg} / \mathrm{kg}$ b.wt (Group II), $\mathrm{As}_{2} \mathrm{O}_{3} 4 \mathrm{mg} / \mathrm{kg}$ b.wt (Group III), and $\mathrm{As}_{2} \mathrm{O}_{3} \quad 8 \mathrm{mg} / \mathrm{kg}$ b.wt (Group IV). Data represented as mean $\pm \mathrm{SD}, n=6 . p<0.05$ was considered significant. $p<0.05$

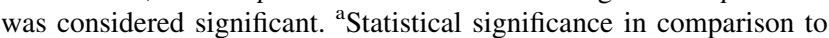
normal control, ${ }^{\text {}}$ statistical significance in comparison to group II, and ${ }^{c}$ statistical significance in comparison to group III

group I control. In statistical analysis, the intergroup comparison between $\mathrm{As}_{2} \mathrm{O}_{3}$-treated groups II, III and IV showed significant variation with respect to the increase in dose of $\mathrm{As}_{2} \mathrm{O}_{3}$ (Table 1).

$\mathrm{As}_{2} \mathrm{O}_{3}$-induced alterations in the antioxidant status

The tripeptide GSH was reduced significantly with respect to the control and was noticed in the arsenic-treated groups. $\mathrm{As}_{2} \mathrm{O}_{3}$ treatment also decreased the GSH-dependant antioxidant enzymes, GST and GPx, and the antiperoxidative enzymes, SOD and CAT, when compared to the group I control and between the arsenic-treated groups II, III and IV. These reductions in the antioxidant enzyme activities

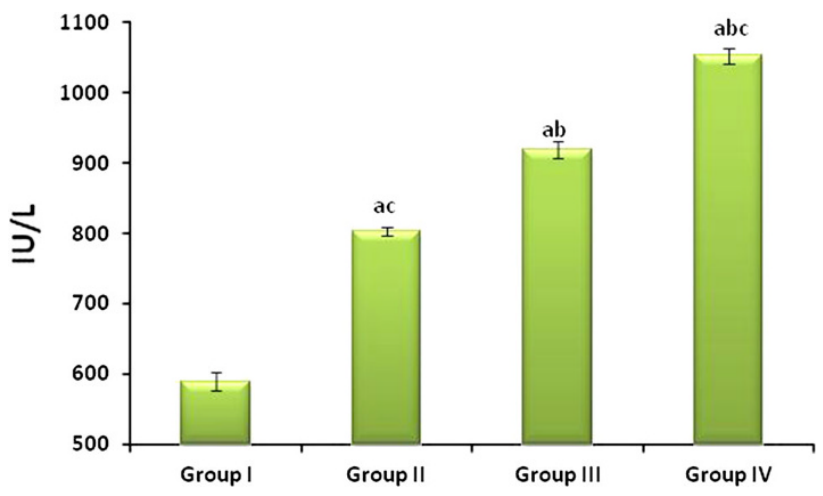

Fig. 3 Effect of $\mathrm{As}_{2} \mathrm{O}_{3}$ on Lactate Dehydrogenase: Normal control (Group I), $\mathrm{As}_{2} \mathrm{O}_{3} 2 \mathrm{mg} / \mathrm{kg}$ b.wt (Group II), $\mathrm{As}_{2} \mathrm{O}_{3} 4 \mathrm{mg} / \mathrm{kg}$ b.wt (Group III), and $\mathrm{As}_{2} \mathrm{O}_{3} 8 \mathrm{mg} / \mathrm{kg}$ b.wt (Group IV). Data represented as mean $\pm \mathrm{SD}, n=6 . p<0.05$ was considered significant. ${ }^{\text {a Statistical }}$ significance in comparison to normal control, ${ }^{b}$ statistical significance in comparison to group II, and ${ }^{\mathrm{c}}$ statistical significance in comparison to group III

were in accordance with the increase concentration of $\mathrm{As}_{2} \mathrm{O}_{3}$ (Table 1).

\section{Discussion}

$\mathrm{As}_{2} \mathrm{O}_{3}$ is an effective cancer therapeutic drug for acute promyelocytic leukaemia and has potential anticancer activity against a wide range of solid tumours ( $\mathrm{Lu}$ et al. 2007). The adverse effects that have been noted in clinical trials of $\mathrm{As}_{2} \mathrm{O}_{3}$ are fluid retention, cardiac toxicity, hepatocellular toxicity and electrocardiographic changes (Soignet et al. 2001). The duration of the present study was selected based on the previous clinical study (Huan et al. 2000). They have reported that $\mathrm{As}_{2} \mathrm{O}_{3}$ treatment resulted in significant remission in APL patients. The $\mathrm{As}_{2} \mathrm{O}_{3}$ concentrations in our study are in the range of clinically available concentrations for anti-leukaemia treatment $(\mathrm{Li}$ et al. 2002).

In the present study, the treatment with $\mathrm{As}_{2} \mathrm{O}_{3}$ increased the glucose concentration in serum. Miller et al. (2002) reported that trivalent arsenic inhibits the uptake of glucose into cells, gluconeogenesis, fatty acid oxidation and further production of acetyl CoA. Pyruvate dehydrogenase, an enzyme of glucose metabolism, is susceptible to arsenicinduced reactive oxygen species (ROS) generation (Aposhian and Aposhian 2006). The thiol moiety is an important target for arsenic (Flora 2011). The increased concentration of glucose in this study, may be due to the binding of arsenic to the sulfhydryl groups of glucose metabolising enzymes, and thereby blocked the uptake of glucose. The altered blood sugar level may also due to islet cells toxicity, because arsenic administration caused severe pancreatic damage (Mukherjee et al. 2004). In our 
Table 1 Effect of $\mathrm{As}_{2} \mathrm{O}_{3}$ on the Blood Antioxidant Status: Normal control (Group I), $\mathrm{As}_{2} \mathrm{O}_{3} 2 \mathrm{mg} / \mathrm{kg}$ b.wt (Group II), As $\mathrm{O}_{3} 4 \mathrm{mg} / \mathrm{kg}$ b.wt (Group III), and $\mathrm{As}_{2} \mathrm{O}_{3} 8 \mathrm{mg} / \mathrm{kg}$ b.wt (Group IV)

\begin{tabular}{|c|c|c|c|c|}
\hline Parameters & Group I & Group II & Group III & Group IV \\
\hline MDA $(\mu \mathrm{M} / \mathrm{L})$ & $4.09 \pm 0.12$ & $4.68 \pm 0.17^{\mathrm{ac}}$ & $4.9 \pm 0.09^{\mathrm{ab}}$ & $5.05 \pm 0.11^{\mathrm{abc}}$ \\
\hline $\mathrm{GSH}(\mu \mathrm{M} / \mathrm{gHb})$ & $5.87 \pm 0.32$ & $5.16 \pm 0.2^{\mathrm{ac}}$ & $4.47 \pm 0.32^{\mathrm{ab}}$ & $3.84 \pm 0.42^{\mathrm{abc}}$ \\
\hline $\mathrm{SOD}(\mathrm{U} / \mathrm{mgHb})$ & $1.59 \pm 0.13$ & $1.32 \pm 0.12^{\mathrm{ac}}$ & $0.98 \pm 0.14^{\mathrm{ab}}$ & $0.75 \pm 0.17^{\mathrm{abc}}$ \\
\hline CAT (k/ml) & $10.31 \pm 0.45$ & $9.12 \pm 0.85^{\mathrm{ac}}$ & $8.28 \pm 0.65^{\mathrm{ab}}$ & $7.44 \pm 0.47^{\mathrm{abc}}$ \\
\hline GPx (U/gHb) & $7.94 \pm 0.18$ & $7.44 \pm 0.11^{\mathrm{ac}}$ & $7.12 \pm 0.12^{\mathrm{ab}}$ & $6.16 \pm 0.1^{\mathrm{abc}}$ \\
\hline GST $(\mu \mathrm{M} / \mathrm{min} / \mathrm{gHb})$ & $2.09 \pm 0.11$ & $1.64 \pm 0.09^{\mathrm{ac}}$ & $1.35 \pm 0.09^{\mathrm{ab}}$ & $0.76 \pm 0.07^{\mathrm{abc}}$ \\
\hline
\end{tabular}

Data represented as mean $\pm \mathrm{SD}, n=6$

$p<0.05$ was considered significant

a Statistical significance in comparison to normal control

b Statistical significance in comparison to group II

c Statistical significance in comparison to group III

observation, the treatment with $\mathrm{As}_{2} \mathrm{O}_{3}$-induced ROS production, which may reduce insulin production by pancreatic cellular damage, leads to the increased glucose concentration in serum.

$\mathrm{As}_{2} \mathrm{O}_{3}$ administration caused myocardial damage and increased release of $\mathrm{CK}$ and $\mathrm{LDH}$ in serum (Raghu et al. 2009). In our recent report, the $\mathrm{As}_{2} \mathrm{O}_{3}$ treatment caused oxidative stress and structural aberrations in the cardiac tissue of experimental rats (Mathews et al. 2013). So the increased concentration of CK and LDH observed in this investigation may be due to the exudation of enzymes from cells to the systemic circulation because of cellular damage induced by the $\mathrm{As}_{2} \mathrm{O}_{3}$.

From our observation, it is found that the MDA production in blood is significantly increased with $\mathrm{As}_{2} \mathrm{O}_{3}$ treatment. MDA is a marker of endogenous lipid peroxidation. Liu et al. (2001) reported that the treatment with arsenic caused a significant increase in the rate of formation of ROS such as superoxide anion radical, hydroxyl radical and hydrogen peroxide. The toxic potential exerted by these compounds is through their reactivity with sulphur containing compounds and the generation of ROS (Hughes et al. 2011). Arsenic-induced MDA production could be due to the impairment of cells' natural protective system and could be directly related to the GSH depletion in blood cells (Wang et al. 2006). Higher the rate of MDA production corresponds to $\mathrm{As}_{2} \mathrm{O}_{3}$ inversely associated with GSH. Depletion of GSH results in the increased production of arsenic-induced ROS, which may enhance the lipid peroxidation as observed in the present study.

The most significant alteration in the antioxidant defence is the decrease in GSH concentration, and GSH has direct antioxidant activity (Schulz et al. 2000). In this study, $\mathrm{As}_{2} \mathrm{O}_{3}$-treated rats showed decreased concentration of GSH and GSH-dependant antioxidant enzymes GPx and GST. This reduction is suggested to be due to the consumption of glutathione while protecting against the arsenic-induced oxidative stress, for maintaining cellular redox status (Hughes 2002). $\mathrm{As}_{2} \mathrm{O}_{3}$ administration reduced the antioxidant and antiperoxidative enzyme concentration in liver tissue of experimental rats (Mathews et al. 2012a). GPx and GST play an important role in arsenic detoxification and the arsenic-induced oxidative stress (Thompson et al. 2009). GST utilises GSH as a cofactor, and therefore, the decrease in the activity of GST after $\mathrm{As}_{2} \mathrm{O}_{3}$ treatment may suggest coming from the paucity of GSH.

The exposure to arsenic decreased the activities of antiperoxidative enzymes SOD and CAT. The decreased SOD activity in serum suggested that the accumulation of superoxide anion radical might be responsible for increased lipid peroxidation following arsenic treatment (Maiti and Chatterjee 2000). ROS can themselves reduce the activity of the antioxidant enzymes CAT and GPx (Datta et al. 2000). Reduction in the antioxidant and antiperoxidative enzymes during $\mathrm{As}_{2} \mathrm{O}_{3}$ treatment may leads to the deposition of arsenic in tissues (Mathews et al. 2012b). SOD catalyses the dismutation of superoxide anions and prevents the subsequent formation of hydroxyl radicals in blood cells (Wang et al. 2006). In the present study, the decreased SOD activity may suggest that the accumulation of superoxide anion radical; might be responsible for increased lipid peroxidation following arsenic treatment as observed by Maiti and Chatterjee (2000). Exposure to arsenic decreased the CAT activity. CAT catalyses the removal of $\mathrm{H}_{2} \mathrm{O}_{2}$ formed during the reaction catalysed by SOD (Lee and Ho 1995). In the present study, the decreased CAT activity indicates the impaired ability to detoxify $\mathrm{H}_{2} \mathrm{O}_{2}$ and may leads to the accumulation of $\mathrm{H}_{2} \mathrm{O}_{2}$ and thereby oxidative stress. 


\section{Conclusion}

In the current investigation, $\mathrm{As}_{2} \mathrm{O}_{3}$ treatment at its clinically different concentrations induced toxic effects by varying the blood glucose, $\mathrm{CK}, \mathrm{LDH}$ and the oxidative status. $\mathrm{As}_{2} \mathrm{O}_{3}$-induced oxidative stress and the lipid peroxidation may be due to the reduced activity of GSH and GSH-dependant antioxidant and antiperoxidative enzymes. We also suggest that further studies are necessary for identifying the cellular and molecular mechanism of toxicity of arsenic at its clinical concentrations.

Acknowledgments We thank the University Grants Commission, New Delhi for rendering financial support for the study (F. No: 39-683/2010SR) and the award of research fellowship in sciences for meritorious student to Mr. Mathews. V. Varghese (No. F.4-1/2006 (BSR)/11-29/2008(BSR)).

Conflict of interest The authors declare that they have no conflict of interest.

Open Access This article is distributed under the terms of the Creative Commons Attribution License which permits any use, distribution, and reproduction in any medium, provided the original author(s) and the source are credited.

\section{References}

Aebi H (1984) Catalase in vitro. Methods Enzymol 105:121-126

Aposhian HV, Aposhian MM (2006) Arsenic toxicology: five questions. Chem Res Toxicol 19:1-15

Basu A, Mahata J, Gupta S, Giri AK (2001) Genetic toxicology of a paradoxical human carcinogen, arsenic: a review. Mutat Res 488:171-194

Beutler E, Duron O, Kelly BM (1963) Improved method for the determination of blood glutathione. J Lab Clin Med 61:882-888

Beutler E, Gelbart T, Pegelow C (1986) Erythrocyte glutathione synthetase deficiency leads not only to glutathione but also to glutathione-S-transferase deficiency. J Clin Invest 77:38-41

Buege JA, Aust SD (1978) The thiobarbituric acid assay. Meth Enzymol 52:306-307

Datta K, Sinha S, Chattopadhyay P (2000) Reactive oxygen species in health and disease. Natl Med J India 13:304-310

Drabkin DL, Austin JH (1932) Spectrophotometric studies. I. Spectrophotometric constants for common hemoglobin derivatives in human, dog, and rabbit blood. J Biol Chem 98:719-733

Flora SJ (2011) Arsenic-induced oxidative stress and its reversibility. Free Radic Biol Med 51:257-281

Huan SY, Yang CH, Chen YC (2000) Arsenic trioxide therapy for relapsed acute promyelocytic leukemia: an useful salvage therapy. Leuk Lymphoma 38:283-293

Hughes MF (2002) Arsenic toxicity and potential mechanisms of action. Toxicol Lett 133:1-16

Hughes MF, Beck BD, Chen Y, Lewis AS, Thomas DJ (2011) Arsenic exposure and toxicology: a historical perspective. Toxicol Sci 123:305-332

Keyse SM, Applegate LA, Tromvoukis Y, Tyrrell RM (1990) Oxidant stress leads to transcriptional activation of the human heme oxygenase gene in cultured skin fibroblasts. Mol Cell Biol 10:4967-4969
Lee TC, Ho IC (1995) Modulation of cellular antioxidant defense activities by sodium arsenite in human fibroblasts. Arch Toxicol 69:498-504

Li Y, Sun X, Wang L, Zhou Z, Kang YJ (2002) Myocardial toxicity of arsenic trioxide in a mouse model. Cardiovasc Toxicol 2:63-73

Liu SX, Athar M, Lippai I, Waldren C, Hei TK (2001) Induction of oxyradicals by arsenic: implication for mechanism of genotoxicity. Proc Natl Acad Sci USA 98:1643-1648

Lu J, Chew EH, Holmgren A (2007) Targeting thioredoxin reductase is a basis for cancer therapy by arsenic trioxide. Proc Natl Acad Sci USA 104:12288-12293

Maiti S, Chatterjee AK (2000) Differential response of cellular antioxidant mechanism of liver and kidney to arsenic exposure and its relation to dietary protein deficiency. Environ Toxicol Pharmacol 8:227-235

Mathews VV, Binu P, Sauganth Paul MV, Abhilash M, Manju A, Nair RH (2012a) Hepatoprotective efficacy of curcumin against arsenic trioxide toxicity. Asian Pac J Trop Biomed 2(2):S706S711

Mathews VV, Paul MS, Abhilash M, Manju A, Abhilash S, Nair RH (2012b) Mitigation of hepatotoxic effects of arsenic trioxide through omega-3 fatty acid in rats. Toxicol Ind Health. doi:10. $1177 / 0748233712463778$

Mathews VV, Paul MV, Abhilash M, Manju A, Abhilash S, Nair RH (2013) Myocardial toxicity of acute promyelocytic leukaemia drug-arsenic trioxide. Eur Rev Med Pharmacol Sci Suppl $1: 34-38$

Miller WH Jr, Schipper HM, Lee JS, Singer J, Waxman S (2002) Mechanisms of action of arsenic trioxide. Cancer Res 62:3893-3903

Mukherjee S, Das D, Darbar S, Mukherjee M, Das AS, Mitra C (2004) Arsenic trioxide generates oxidative stress and islet cell toxicity in rabbits. Curr Sci 86:854-857

Paglia DE, Valentine WN (1967) Studies on the quantitative and qualitative characterization of erythrocyte glutathione peroxidase. J Lab Clin Med 70:158-169

Paoletti F, Aldinucci D, Mocali A, Caparrini A (1986) A sensitive spectrophotometric method for the determination of superoxide dismutase activity in tissue extracts. Anal Biochem 154:536-541

Raghu KG, Yadav GK, Singh R, Prathapan A, Sharma S, Bhadauria S (2009) Evaluation of adverse cardiac effects induced by arsenic trioxide, a potent anti-APL drug. J Environ Pathol Toxicol Oncol 28:241-252

Ratnaike RN (2003) Acute and chronic arsenic toxicity. Postgrad Med J 79:391-396

Rust DM, Soignet SL (2001) Risk/benefit profile of arsenic trioxide. Oncologist 6(suppl 2):29-32

Schulz JB, Lindenau J, Seyfried J, Dichgans J (2000) Glutathione, oxidative stress and neurodegeneration. Eur J Biochem 267: 4904-4911

Soignet SL, Frankel SR, Douer D, Tallman MS, Kantarjian H, Calleja E, Stone RM, Kalaycio M, Scheinberg DA, Steinherz P, Sievers EL, Coutré S, Dahlberg S, Ellison R, Warrell RP Jr (2001) United States multicenter study of arsenic trioxide in relapsed acute promyelocytic leukemia. J Clin Oncol 19:3852-3860

Tchounwou PB, Wilson B, Ishaque A (1999) Important considerations in the development of public health advisories for arsenic and arsenic-containing compounds in drinking water. Rev Environ Health 14:211-229

Thompson JA, White CC, Cox DP, Chan JY, Kavanagh TJ, Fausto N, Franklin CC (2009) Distinct Nrf1/2-independent mechanisms mediate As 3+-induced glutamate-cysteine ligase subunit gene expression in murine hepatocytes. Free Radic Biol Med 46:1614-1625 
Tseng CH, Chang CK, Tseng CP, Hsueh YM, Chiou HY, Tseng CC, Chen CJ (2003) Long-term arsenic exposure and ischemic heart disease in arseniasis-hyperendemic villages in Taiwan. Toxicol Lett 137:15-21

Vega L, Gonsebatt ME, Ostrosky-Wegman P (1995) Aneugenic effect of sodium arsenite on human lymphocytes in vitro: an individual susceptibility effect detected. Mutat Res 334:365-373
Wang ZY, Chen Z (2008) Acute promyelocytic leukemia: from highly fatal to highly curable. Blood 111:2505-2515

Wang L, Xu ZR, Jia XY, Jiang JF, Han XY (2006) Effects of arsenic (As-III) on lipid peroxidation, glutathione content and antioxidant enzymes in growing pigs. Asian Aust J Anim Sci 5:727-733 